\title{
Ageing and Inclusion in Rural Areas
}

\author{
Ira VERMA ${ }^{\mathrm{a}, 1}$ and Jonna TAEGEN ${ }^{\mathrm{b}}$ \\ a SOTERA research group, Department of Architecture, Aalto University \\ ${ }^{\mathrm{b}}$ Department of Architecture, Aalto University
}

\begin{abstract}
.
This paper is presenting a research and development project related to areas with decreasing and ageing population. The focus of the study is on housing and the inclusion of older people in rural communities. The case study method was implemented in three shrinking municipalities in remote areas. The population loss in small ageing municipalities is affecting the number of local services as well as access to public transport. Most people 75 years old and older live in owner occupied single-family houses. The accessibility renovations of these houses for low-income older residents are challenging. Strategic long-term concepts are needed to improve the housing for older people and the urban quality of small municipal centers. Initiatives focusing on wellbeing and social cohesion are needed to enable people to remain living in rural areas in the future. Actions related to planning and services for the older population should contribute to social cohesion within the community. A dense and walkable municipal center with accessible apartments may help municipalities provide for their older populations. Future developments need to be based on resource efficiency and an intergenerational approach to keep these municipalities good places to live.
\end{abstract}

Keywords. older people, rural areas, accessibility, mobility

\section{Introduction}

This paper is presenting a multiple case study implemented in small municipalities. The research and development project is related to areas with decreasing and ageing population. Shrinkage is a process leading to population decline, loss of services and investments. It is affecting many small communities. To manage shrinkage, some studies propose improvements targeted to the quality of living, networking locally, and developing areas of growth such as the green and silver economies [1]. This paper focuses on housing and mobility options from the point of view of the older population living in these small municipalities. The research and development project Viable communities $(2018$ - 2020) was implemented in five municipalities or joint municipalities in remote areas with a shrinking population. Three of these municipalities - Keuruu, Kauhajoki, and Pertunmaa - are studied more in detail in this paper (Figure 1). Each of the municipalities has less than 15000 inhabitants and is facing challenges of managing their urban structure and providing services for the declining population. At

\footnotetext{
${ }^{1}$ Corresponding author, Ira Verma, Department of Architecture, Aalto University, PoBox 31000, 00076 Aalto, Finland; E-mail: ira.verma@aalto.fi
} 
the same, these municipalities have many positive features related to clean nature and water, a way of living, and a strong community. These are potential strengths for future developments as rural areas may promote resident's feeling of inclusion, and general well-being that is not found in the cities.

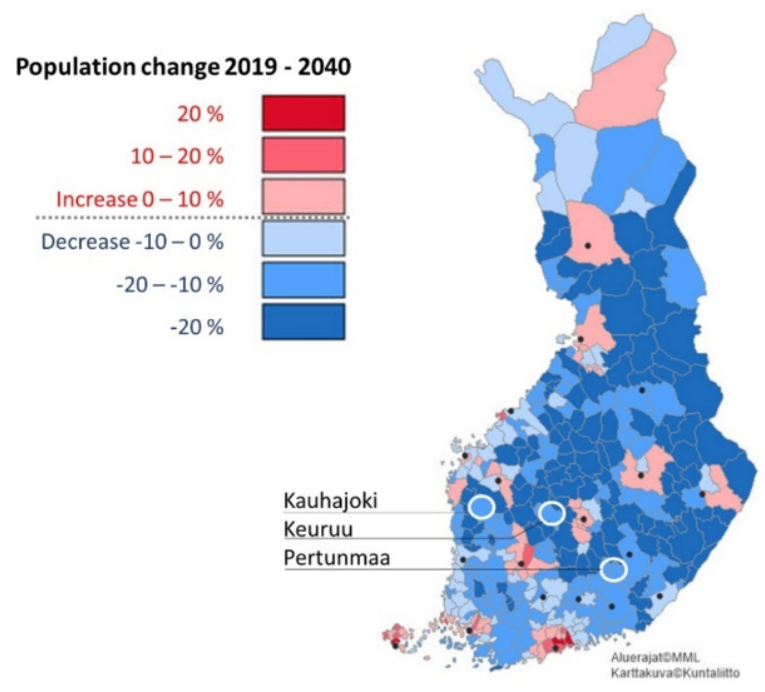

Figure 1. The municipalities participating in the study are located in the shrinking regions in Finland.

This project aimed at assessing the local potentials and support the urban long-term strategy to keep these small municipalities good places to live in even in the future. The project was carried out at the university in collaboration with the municipalities, and with the support of the Housing Finance and Development Centre of Finland, the Ministry of the Environment as well as the Ministry of the Social Affairs and Health.

\section{Background}

The depopulation of small ageing municipalities is affecting the possibilities to deliver public services. It is also making it difficult to maintain local services or cultural events. This development leads to a longer distance to services and reduces access to them. Since 2005, due to decreasing birth rates in Finland, e.g. one-third of the primary schools have been closed or moved to bigger municipalities [2]. This drives families with children to bigger cities, which has a negative effect on the demographic structure of small municipalities. According to population projections for 2040, while the total population in remote areas is shrinking, the percentage of the age cohort 75 years old and over is projected to increase by $10 \%$ [3]. It may lead to higher needs for service delivery in these areas. A study carried out in the US indicated that due to ageing of the population the disability is disproportionately found in rural areas [4]. It noted that even though disability has little influence on residential preferences and choice between rural or urban living environments, older people and households with a family member with a disability have a higher overall tendency to stay in place. Additionally, the challenges in accessibility in rural areas may result in a higher self-reported disability. 
Housing is a basic need and affects our general wellbeing. As small rural communities have a very slow pace of change in the housing stock [5], the immediate development needs are related to existing housing stock and how it can best meet the needs of an ageing population. In Finland, most older people live in owner-occupied single-family houses, especially in rural areas. The results of a recent survey targeted to the Councils for older people showed that almost half $(45 \%)$ of the councils in small municipalities considered that there are not enough housing choices for older people in their area [6]. Another survey observed that many world war II veterans in rural areas still lived in poorly equipped single-family houses [7]. The differences in income and wealth influence older people's choice of housing and their possibility to make accessibility renovations of their housing.

Older people may have challenges to be included in the community, to maintain their physical and social activity in areas with long distances. The visits to a local grocery may be an important social activity for people with mobility restrictions, and for those whose social relations are becoming fewer. In rural areas, the access to local services becomes a major challenge for older people, who no longer have the possibility to use their car. Dwyer and Hardill (2011) argue, that the lack of transport options, the closure of local shops and services, and the decline of functioning capacities combined, reduce opportunities for everyday social interaction in remote areas [8]. They observed that the village services, such as lunch clubs and information services, played an important role in supporting older rural residents by providing opportunities for social interaction and contact with the wider community. They found that these services were used mainly by women and pointed out the need to find ways of engaging men.

\section{Methods and sample}

This research project used a multiple case study method [9]. Comparative analyses of local resources, building stock, and transport connections, were carried out. The study included a survey to local residents, discussions with municipal authorities, and workshops with residents and other relevant stakeholders. This paper is focusing on the results of the survey. In two of the municipalities, the survey targeted to residents was published online and distributed in paper format. The third municipality had made an internal survey for its residents in 2017 which was used as a reference [10]. The response rate in the municipalities varied. The smallest municipality, Pertunmaa, had the best response rate. A paper format questionnaire was sent by post to all permanent households and second home owners in the municipality $(\mathrm{N}=910)$. The total number of responses was 576 . Whereas, we received only 59 responses from largest municipality Kauhajoki. This may indicate that a personal invitation to take part in the study, especially among older people is more successful. In Keuruu, 250 households had responded to the survey. 
Table 1. Total population and population 75 years old and older in 2019 and prognostic till 2040.

\begin{tabular}{rcrrr}
\hline & $\begin{array}{c}\text { Total population } \\
\mathbf{2 0 1 9}\end{array}$ & $\begin{array}{c}\text { Population 75 } \\
\text { years old and } \\
\text { older 2019 }\end{array}$ & $\begin{array}{c}\text { Population } \\
\text { prognostics } \\
\mathbf{2 0 4 0}\end{array}$ & $\begin{array}{c}\text { Population } \\
\text { prognostics 75 years } \\
\text { old and older 2040 }\end{array}$ \\
\hline Pertunmaa & 1687 & 283 & 1366 & 380 \\
Kauhajoki & 13206 & 1467 & 10560 & 2475 \\
Keuruu & 9639 & 1372 & 7946 & 2064 \\
\hline
\end{tabular}

\section{Results}

\subsection{The urban environment}

According to the definition of the Official Statistics Finland, all clusters of buildings with at least 200 inhabitants and where the distance between buildings does not exceed 200 metres are defined as statistical localities. During the period from 1970 to 2018, the number of these localities has decreased by 30 percent, and in 2018 it was 732 [11]. The municipalities participating in this research project have each two or three statistical localities. In Kauhajoki and Keuruu, the majority of the population is living in the administrative centre of the municipality. In Pertunmaa the number of inhabitants is divided more regularly between the municipal centre and its surrounding area. The population density varies within these municipalities. In Kauhajoki the density is 10,2 inhabitants per $\mathrm{km}^{2}$, in Keuruu 7,6 inhabitants per $\mathrm{km}^{2}$, and in Pertunmaa only 4,5 inhabitants per $\mathrm{km}^{2}$. A significant number of inhabitants in Kauhajoki (32\%), Keuruu (29\%) and Pertunmaa (58 \%) live outside the localities in sparsely populated areas [12].

The Kauhajoki municipal centre is located along a river (Figure 2, left). The commercial and public services are found on two parallel roads which are going through the administrative centre. This linear structure leads to long distances between both ends of the centre. The bus station, marked as a red dot on the map, is located in the middle. The public services are within a $500 \mathrm{~m}$ distance from the bus station.

The administrative centre of Keuruu is located on an island (Figure 2, centre). Originally, the commercial services were placed along the main street crossing the island from south to north. A new commercial service concentration is building up outside the old municipal centre close to the highway and next to the railway in the south. This has led to the closure of some small retail shops and vacant commercial facilities in the centre. The bus station, marked in red, is between the old and new centre serving both centres. The public services are located mainly in the northern part of the island.

The municipality of Pertunmaa has two strong centres. The old centre with public services is located by a lake (Figure 2, right). The public and local services are found within a radius of $500 \mathrm{~m}$ to the main street crossing the municipal centre. A new commercial centre is building up near the highway at $10 \mathrm{~km}$ distance from the old center. There is no public transport to the old centre or between the commercial and old centre. Increasingly, the commercial services and jobs are moving from the old centre to the commercial centre. However, most of the residents live near the old centre. These two centres weaken the viability of each other. 


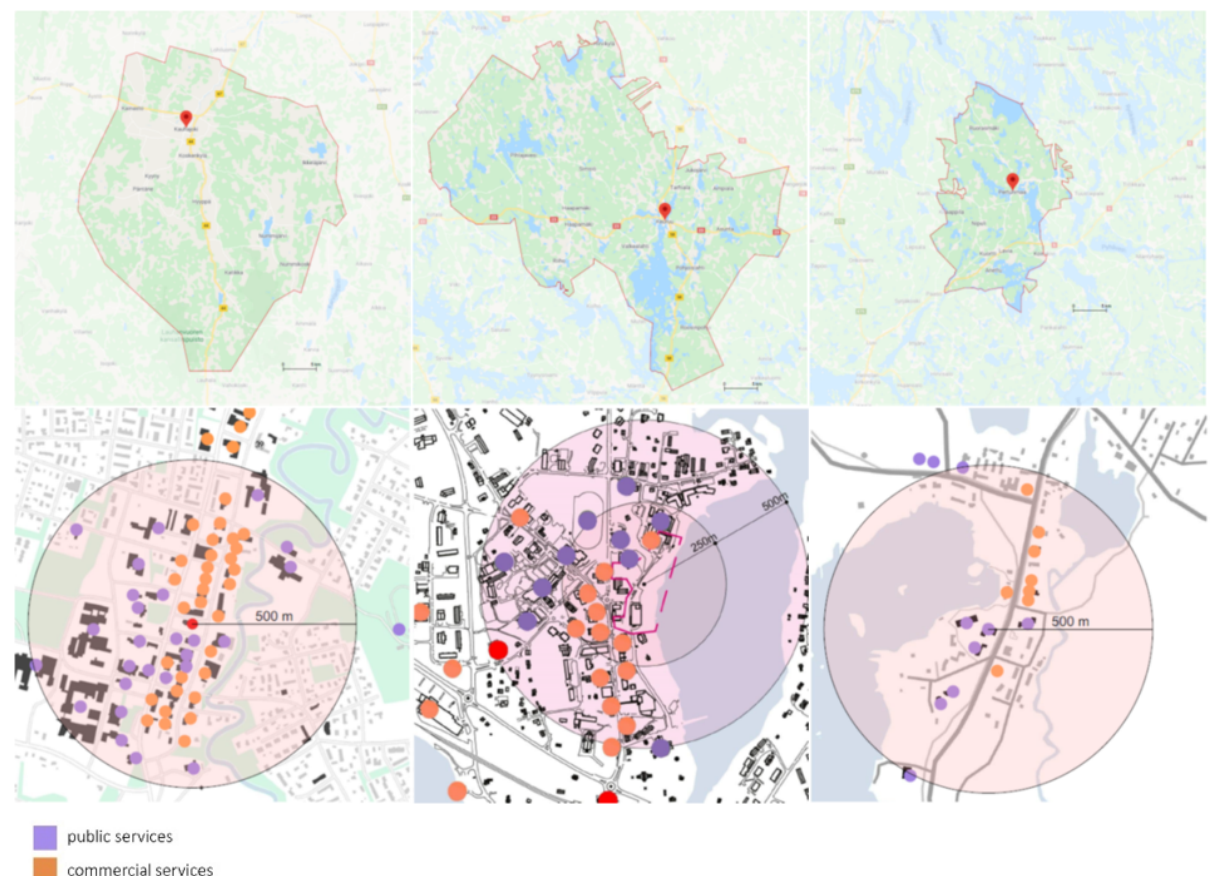

Figure 2. Kauhajoki, Keuruu, Pertunmaa (from left to right)

In each of the municipalities, the current development process leads to a dispersed urban structure where commercial services and supermarkets are moving near the highway away from housing areas. It increases the walking distances to the services or makes people dependent on their car which creates challenges especially for older people, who are not driving. The lack of public transport makes older people dependent on relatives and neighbours it may also increase the need for services from the public service provider.

\subsection{Housing situation of older people}

In small municipalities in remote areas majority of people live in detached houses. In Pertunmaa $70 \%$, in Kauhajoki $67 \%$, and Keuruu $51 \%$ of all households live in singlefamily homes. However, in the age cohort 75 years old and over, people live more often in row houses and apartment blocks than in other age groups (Figure 3) ${ }^{2}$ [13]. The home environment may become a challenge when the functional capacities decline, and the environment does not support the daily tasks. Some studies indicate that old age and disability are factors of residential mobility. Especially the maintenance tasks and gardening in a detached house may become a burden. The current care policy is promoting ageing in place. The provision of various housing choices may enhance independent living. Keuruu has the biggest offer of apartments in the municipal center and fewer older people are living in single-family houses.

${ }^{2}$ Official Statistics Finland. 


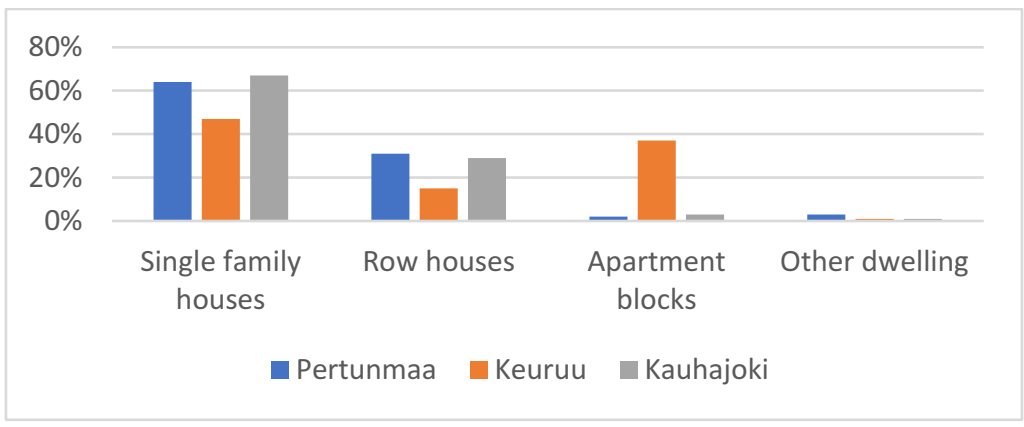

Figure 3. Housing mode of the population 75 years old and older.

In all participating municipalities, more than $90 \%$ of people 75 years old and older live at home (Table 2) [14]. The availability of suitable apartments for older people is the precondition of living at home at old age. The majority of the population 75 years old and older live alone in single person households. In Keuruu, 52 \% single person households, where the resident is 75 years old and older and female live in apartment blocks. Older women in that age category living alone in detached houses represent only $19 \%$ of the households. The larger offer of apartments in the center of the municipality may also be one of the reasons for the lower percentage of the older population in 24hour care services in Keuruu. It is smaller $(6,2 \%)$ than in the other two municipalities, Pertunmaa $(9,2 \%)$ or Kauhajoki (9,9\%) [14]. In long term, the supply of accessible apartments near services may bring economic benefits to the municipality.

Table 2. Housing in the age group of people 75 years old and older.

\begin{tabular}{rcc}
\hline & Living at home & In 24-hour care services \\
\hline Pertunmaa & $90.8 \%$ & $9,20 \%$ \\
Kauhajoki & $90.0 \%$ & $9,90 \%$ \\
Keuruu & $92.5 \%$ & $6,20 \%$ \\
\hline
\end{tabular}

\subsection{Access to Services}

In rural areas, the distances to services are longer than in urban areas. Due to lack of public transport, access to daily services may become difficult. Furthermore, the municipal centers of rural areas are based on car use and have less focus on walkability. In the participating municipalities, only 10 to 20 percent of the population live within $500 \mathrm{~m}$ walking distance from services (Table 3) [15]. The residents in remote municipalities are car dependent and older people who have stopped driving may have difficulties accessing the local services. Furthermore, in rural municipalities, the pedestrians may need to share the same street with bicycles or even cars. This may decrease the feeling of safety.

Table 3. Distance to local services from home, $\%$ of the population.

\begin{tabular}{llll}
\hline Distance to service & $\begin{array}{l}\text { Kauhajoki, } \\
\text { \% of population }\end{array}$ & $\begin{array}{l}\text { Keuruu } \\
\text { \%o of population }\end{array}$ & $\begin{array}{l}\text { Pertunmaa } \\
\text { \% of population }\end{array}$ \\
\hline Less than $500 \mathrm{~m}$ & $11.2 \%$ & $21.7 \%$ & $17.1 \%$ \\
Less than $1 \mathrm{~km}$ & $32.1 \%$ & $44.9 \%$ & $32.6 \%$ \\
Less than $5 \mathrm{~km}$ & $80.4 \%$ & $79.3 \%$ & $79.5 \%$ \\
\hline
\end{tabular}


The results of the survey indicated the importance of owning a car. In Keuruu 60 percent of the inhabitants reported using their car to access services in their daily life. In Kauhajoki and Pertunmaa more than nine out of ten residents used their car. The specialized shops, cultural and leisure services are located in bigger towns which increased the travel distances. Several times a month, the inhabitants used services located within 30-60 km distance from their place of residence. Services at $100 \mathrm{~km}$ distance were visited less seldom. In Kauhajoki, the residents reported to use the services in Seinäjoki, a town $57 \mathrm{~km}$ from the municipal centre. In Pertunmaa, residents used local services in the commercial center $10 \mathrm{~km}$ from the municipal center and in several smaller towns within $60 \mathrm{~km}$. Only a few persons reported using only services in their municipal centre [16]. The results of the survey in Keuruu showed that the amount of online shopping was also significant (Figure 4). The importance and share of remote services have been increasing dramatically during the pandemic. All people, however, do not have access to them.

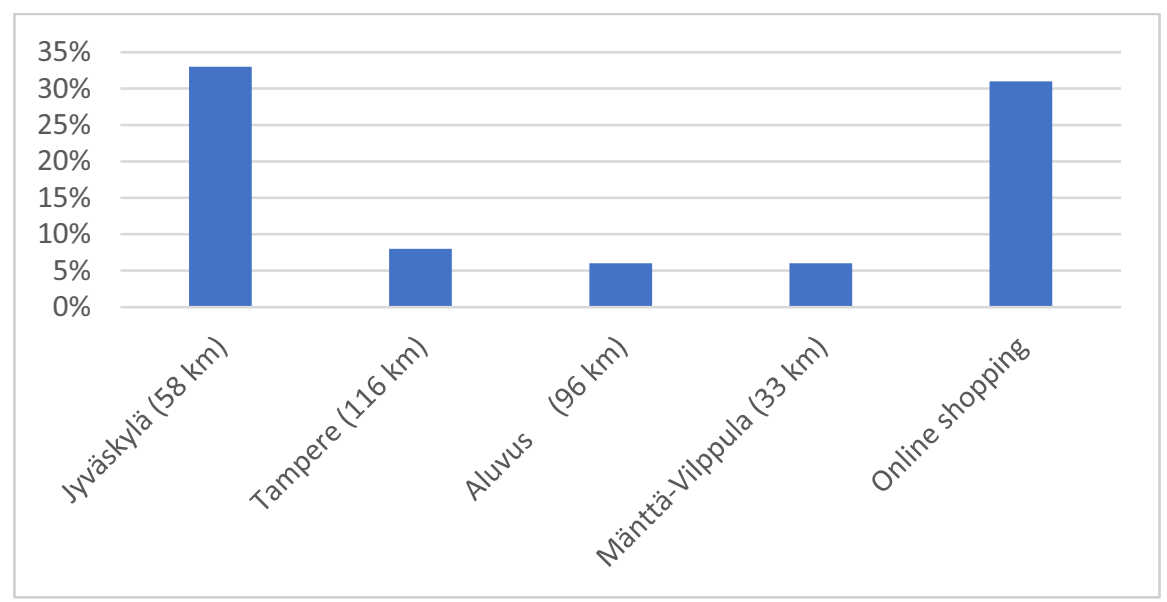

Figure 4. Services are used several times a month in the neighbouring cities of Keuruu.

\subsection{Residents' self-reported targets for the municipal development}

Residents were asked to report, what were the best features in their living environment, and which ones should be improved to make their municipality more attractive and viable. As a response to open-ended questions, they reported that nature, a peaceful and safe environment, as well as friendly people were the most valued aspects of living in a small municipality (Table 4). The majority of them found that the basic needs for services were met and their municipality was a good place to live in.

Table 4. The best thing in the municipality

\begin{tabular}{lll}
\hline Kauhajoki & Keuruu & Pertunmaa \\
\hline 1. services & 1. safety & 1. nature \\
2. nature & 2. nature & 2. calmness \\
3. people & 3. residence & 3. people \\
\hline
\end{tabular}

Permanent residents in Pertunmaa, in the age cohort 64 years and over, found that the social and health care services, public transport services, and collaboration between 
public service providers and local associations were the most important development tasks [16]. In addition to these development ideas, the residents pointed out the importance of co-operation and preservation of existing services.

In Kauhajoki, the respondents pointed out the need to develop the quality of the built environment, accessibility, and public transport in the municipal centre. Also, they brought out the need to provide more places and facilities for children and adolescents. The events and happenings made the centre more viable. Additionally, more working places and job opportunities would attract new working-age inhabitants and families to the municipality.

In Keuruu, the development possibilities of the administrative centre were expressed more in detail. The refurbishment of the existing building facades, new buildings, new functions to empty buildings, and taking care of the outdoor spaces were considered important.

Nevertheless, when asking the inhabitants, what was the best thing in their municipality, the most common answers were good living environment, nature, and people. Although the number of inhabitants and services are decreasing, and the buildings are getting empty, the shrinking municipalities have their strengths in the beautiful location and the social cohesion.

\section{Conclusion}

According to population prognostics by 2040 in Finland, 259 of 310 municipalities will lose population [17]. Strategic long-term urban planning is needed to improve the quality of the living environment in the shrinking municipalities. The viability of these municipalities is related to the resilience and the global targets of sustainable development. The bottom-up approach, easy communication between various stakeholder and co-design possibilities makes small municipalities agile [18]. Camarero and Oliva (2019) argue that the territorial imbalance between urban and rural areas leads to inequalities in political opportunities, as lower demographic weight implies less political strength [19]. They also point out the generational and gender imbalance is challenging the development in rural areas.

In rural areas, old apartments often lack accessibility and are not suitable for an older population. At the same, the need for accessible and affordable housing is expected to be growing due to the increase of the low-income senior population in rural areas. Housing type presents as an important potential determinant of older people's physical activity levels [20]. The offer of apartment buildings suitable for older people in these small municipal centres enables people to remain living in their familiar surroundings. The residents living in small municipalities appreciate nature, a safe living environment, and friendly people. In the future, the population dependency ratio of these municipalities will get higher than today. By 2040 in Pertunmaa, for example, the ratio will reach 112 [21]. This indicates that each working age person is supporting more than one other person. The economic situation and the delivery of services are becoming a challenge in rural areas if there is not a cross-section of generations. Initiatives focusing on the quality of life and social cohesion are needed to make these places attractive also in the future.

The potential of rural areas is in a strong community. Actions related to planning and service development for the older population should contribute to social cohesion within the community. Furthermore, second-home owners are a potential resource for small municipalities. In rural Finland in the summer, the second-home owners may 
outnumber the permanent residents. The clean nature and water, local culture, and carfree environment attract the visitors. All three municipalities participating in this study were situated in a natural landscape near the waterfront. The potential of nature is not always fully taken advantage of. The development should consider the needs of visitors and second-home owners.

The decrease in access to services in rural areas makes people dependent on their cars. The mobility limitations become a source of new inequalities. Older people in rural areas are more likely than those in urban areas to live far from their family members [22]. A previous study indicated that older people in Nordic countries avoid asking for help from their relatives and neighbours [23]. This may increase the need for support from public service providers. Online services and home delivery of goods can either reduce costs or attract more users. The older people, however, are the least likely to take advantage of remote services [24]. A service hub in the centre of the municipality can be a place of information, mobile and remote services as well as social activities. It may be an attraction to local people and visitors. During the pandemic, many seniors and remote workers exiled to their second home. This enabled them to keep social distancing while having an active lifestyle. A study on mobile data indicated mobility flows from urban areas to less populated rural areas, and there was a strong correlation between the increase of people and the presence of second homes [25]. Mobile work and remote services may attract more people in these areas also in the future.

Putting multiple services in the same physical location brings advantages especially to people with reduced functional capacities. According to a Finnish survey, one-third of the population 75 years old and older have difficulties walking over $500 \mathrm{~m}$ distances [26]. This can be used as a basis for planning a walking friendly environment. The solutions of this study are based on local context. In Pertunmaa, the project resulted in a multiservice hub that was proposed in the existing Municipal Hall located in central position. The urban design in Keuruu was promoting walkability and street lighting in the municipal center. A dense and walkable municipal center with accessible apartments may help municipalities provide for their older populations. Future developments need to be based on an intergenerational approach to have economic viability and services in these areas [27]. The rural areas have many potentials to promote wellbeing and quality of life of the residents. The adaptation to shrinkage, strong intergenerational community, and agility of a small municipality may improve the resilience.

\section{References}

[1] Weyman, T. \& Martinez-Fernandez, C. (2012). Demographic chnage and shrinkage in Australia Communities. In: Demographic Change and Local Development: Shrinkage, Regeneration and Social Dynamics. OECD

[2] Takala, A. "Tilaa hitto itse netistä" - Keskittäminen köyhdyttää Kemijärven kaltaisia pikkukaupunkeja, ja digitalisaation kaikkivoipaisuus on saatettu yliarvioida. [accessed 27.12.2018]. available at: $<$ https://www.hs.fi/kotimaa/art-2000005946454.html>

[3] Official Statistics Finland. 2019.

[4] von Reichter, C. \& Berry, H. (2019), Rural-urban patterns of disability: The role of migration. Population, Space and Place, DOI: $10.1002 /$ psp. 2271

[5] Bevan, M. (2009). Planning for an Ageing Population in Rural England: The Place of Housing Design. Planning Practice and Research, Volume 24(2), https://doi.org/10.1080/02697450902827386

[6] Jalava, J., Lahtinen, H., Tyvimaa, T., Vuorela, M. \& Arolinna, S. (2017). Ikääntyneiden asumisratkaisujen tarve ja toteutus. Ministry of the Environment, Helsinki.

[7] Hillevuo, A. (2013) Veteraanien asuntojen korjaustöiden vaikuttavuusselvitys. The Finnish Association for the Welfare of Older People, Helsinki. 
[8] Dwyer, P. \& Hardill, I. (2011) Promoting social inclusion? The impact of village services on the lives of older people living in rural England. Ageing \& Society, 31 (2). pp. 243-264.

[9] Official Statistics Finland.

[10] City of Keuruu. (2017). Keuruu. Kuntapalvelu- ja asiointikysely 2017. https://www.keuruu.fi/images/ kaavoituspalvelut/dokumentit/Kyselyraportti_10.10.2017.pdf

[11] Urban settlements by population and population density, 2018. Population structure, Statistics Finland [accessed 2.3.2020].

[12] Degree of urbanisation by area, 2018. Population structure, Statistics Finland [accessed 26.02.2020].

[13] Official Statistics Finland.

[14] Sotkanet.fi database, available at $<$ https://sotkanet.fi/sotkanet/en/index? $>$ [accessed 19.02.2020].

[15] Liiteri database. available at: $<$ https://liiteri.ymparisto.fi/ $>$ [accessed 27.02.2020]

[16] Verma, I \& Taegen, J. 2019. Access to Services in Rural Areas From the Point of View of Older Population - A Case Study in Finland. International Journal of Environmental Research and Public Health.

[17] Official statistics Finland. (OSF): Population prognostics [e-publication]. ISSN=1798-5137. 2019. Helsinki: Tilastokeskus available at: <http://www.stat.fi/til//vaenn/2019/vaenn_2019_2019-0930_tie_001_fi.html> [accessed:27.2.2020].

[18] Väisänen, R. (2019). Kohti kestäviä yhdyskuntarakenteita - resilienssin suuntaviivat väestöltään vähenevillä seuduilla. Aalto University, Department of Architecture.

[19] Camarero \& Oliva. (2019). Thinking in rural gap: mobility and social inequalities. Palgrave Communications 5, 95 (2019).

[20] Pettigrew, Rai, R., Jongenelis, M., Jackson, B., Beck, B. \& Newton, R. (2020). The Potential Importance of Housing Type for Older People's Physical Activity. Journal of Applied Gerontology 2020, 39 (3) 285291

[21] OSF, (2019) Demographic dependency ratio by area, 2019-2040 (projection 2019). http://pxnet2.stat.fi/PXWeb/pxweb/en/StatFin/StatFin_vrm_vaenn/statfin_vaenn_pxt_128x.px/

[22] Lundholm, E. (2015). Migration and Regional Differences in Access to Local Family Networks Among 60-year olds in Sweden. Population Ageing, 8, p. 173-185. DOI 10.1007/s12062-015-9117-z

[23] Daatland, S., Salsgavod. B. \& Lima, I. (2009). Population ageing, intergenerational solidarity and the family-welfare state balance: a comparative exploration. In: How generations and gender shape demographic change. UNECE, Geneva, pp. $127-138$.

[24] OECD. (2010). Strategies to Improve Rural Service Delivery. OECD Technical report. DOI 10.1787/9789264083967-en

[25] Willberg E, Järv O, Väisänen T \& Toivonen T. (2021). Escaping from Cities during the COVID-19 Crisis: Using Mobile Phone Data to Trace Mobility in Finland, Int. J. Geo-Inf. 2021, 10, 103. https://doi.org/10.3390/ijgi10020103

[26] Murto J, Kaikkonen R, Pentala-Nikulainen O, Koskela T, Virtala E, Härkänen T, Koskenniemi T, Jussmäki T, Vartiainen E \& Koskinen S. Aikuisten terveys-, hyvinvointi- ja palvelututkimus ATH:n perustulokset 2010-2017. e-publication available at : www.thl.fi/ath

[27] Scott, M.; Gallent, N.; Gkartzios, M. The Routledge Companion to Rural Planning; Routledge: London, UK, USA, 2019; p. 265. 